\author{
Glycine betaine의 급여가 돈육의 품질에 미치는 영향 \\ 박구부* - 허선진* . 양한술* . 이정일*** . 곽석준*** . 이중동*** . 허남응** . 김진성**** . 주선태* \\ 경상대학교 동물자원과학부*, 생명과학부**, 경상남도 첨단양돈연구소***, \\ 동아대학교 식품과학부****
}

\title{
Effect of Dietary Glycine Betaine on Pork Qualities During Storage
}

\author{
G. B. Park*, S. J. Hur*, H. S. Yang*, J. I. Lee***, S. J. Kwck***, J. D. Lee***, N. E. Huh***,
}

J. S. Kim**** and S. T. Joo*

Division of Animal Science*, Division of Natural Science**,

Gyeongsang National University, Gyeongnam Province Advanced Swine Research Institute***,

Division of Food Science, Donga University****

\begin{abstract}
A total of 80 pigs were used to investigate the effect of dietary glycine betaine $(N, N, N$-trimethylglycine $)$ on pork quality during cold storage. About $70 \mathrm{~kg}$ pigs were randomly alloted into one of four experimental diet groups $(0 \%, 0.2 \%, 0.4 \%$ and $0.6 \%$ glycine betaine). Pigs were slaughtered at approximately $110 \mathrm{~kg}$ live weight, and $\mathrm{pH}$, color(CIE $\mathrm{L}^{*} \mathrm{a}^{*} \mathrm{~b}^{*}$ ), shear force, sarcomere length, lipid oxidation and composition of fatty acid were measured in pork loin for 13 days of cold storage. The concentration of glycine betaine in pork loin was significantly increased $(\mathrm{P}<0.05)$ with increasing of glycine betaine level in diet. Pork loins from dietary betaine groups showed significantly higher muscle $\mathrm{pH}$ and lower $\mathrm{CIE} \mathrm{b}^{*}$ values compared to control group after 13 days of storage. There were significant differences in shear force values among pork loins from diet groups at 24 hrs postmortem. However, pork loins from control diet showed longer sarcomere length than those of dietary betaine groups. Dietary glycine betaine increased the ratio of saturated fatty acids and decreased unsaturated fatty acids in pork loins. Especially the ratios of linoleic and myristic acid were decreased with increasing dietary betaine level. However, dietary glycine betaine did not affect lipid oxidation (TBARS) and sensory evaluation during cold storage.
\end{abstract}

(Key words : Glycine betaine, Pork quality, Pig diet, Pork evaluation)

\section{I 서 론}

글라이신 베타인(Glycine betaine; N,N,N-trimethylglycine)은 아미노산인 글라이신의 유도체이 며 미생물, 고등식물 및 인간 등의 조직에서 수분과 염의 스트레스 환경 하에 생합성 된다. 또한 비타민 $\mathrm{B}$ 복합체인 콜린의 분해에 필수적 인 매개체이다. 사람에 있어 글라이신 베타인 은 음식을 통해 섭취되거나 간장에서 콜린의
이화작용을 통해 합성된다(de Zwart 등, 2003). 또한 글라이신 베타인은 당뇨병 환자의 경우 소변을 통해 분비가 증가하나 건강한 사람의 혈청 내에서는 그 농도가 잘 조절되며(Dellow 등, 1999), 글라이신 베타인이 함유된 음식의 섭취를 통해 쉽게 체내 흡수된다(Sizeland 등, 1993). 글라이신 베타인의 주요 공급원은 빵이 나 파스타와 같은 곡류 제품이며, 동물성 식품 으로는 조개와 계육에서 상대적으로 높은 글라

Corresponding author : Seon-Tea Joo, Division of Animal Science, Gyeongsang National University, Kajwa-dong 900, Jinju 660-701, Korea. Tel : 055-751-5511, Fax : 055-756-7171, E-mail : stjoo@gsnu.ac.kr. 
이신 베타인 함량을 나타낸다(de Zwart 등, 2003). 콜린은 레시틴 분자의 중요한 부분을 차 지하고 있는 물질인데, 이러한 콜린이 글라이 신 베타인 섭취에 의해 인지질화합물로 교체되 는 과정에서 레시틴이 체내 지방의 이동을 촉 진시킨다(de Zwart 등, 2003). 그러므로 글라이 신 베타인은 간장뿐만 아니라 근육 내 지방의 축적과 감소에 영향을 미치게 된다. 따라서 글 라이신 베타인의 이러한 지방감소 효과는 저지 방 육류 생산을 위한 방안으로 주목 받고 있다 (Virtanen과 Campbell, 1994).

가축에 있어 글라이신 베타인 연구를 보면, 돼지에게 글라이신 베타인을 급여하였을 때 사 료 효율이 증가되었으며(Campbell 등, 1995; Haydon 등, 1995), 일당증체량이 증가되었다고 보고된 바 있다(Smith 등, 1995). 또한 글라이신 베타인의 급여는 달리는 말의 피로회복 효과가 있다고 보고 되었다(Warren 등, 1999). Lawrence 등(1995)과 Cadogan 등(1993)은 글라이신 베타 인의 급여는 돈육의 등지방 두께를 감소시킨다 고 하였으며, 등심근 단면적을 증가시키고 (Smith 등, 1995), 도체율을 증가시키는 효과 (Matthews 등, 1995) 등이 보고 되었다. 또한 돼 지에 있어 베타인의 급여는 지방의 함량을 줄 이고 육량을 증가시키며(Matthews 등, 2001b), 육계의 도체에 있어 지방의 함량을 줄이는 효 과(Saunderson과 MacKinley, 1990) 등이 보고 되 었다. 그러나 글라이신 베타인 급여가 돈육의 육질에 미치는 영향에 관하여 연구는 많이 이 루어지지 않았다. 따라서 본 연구는 글라이신 베타인의 급여가 돈육의 품질에 미치는 영향 에 관해서 살펴봄으로써 베타인 급여를 통한 고품질 돈육생산 가능성을 알아보고자 수행하 였다.

\section{재료 및 방법}

\section{1. 공시가축}

시험 돼지는 경남 함안군 소재 $\mathrm{P}$ 농장에서 사육중인 돼지 중 평균 체중이 $70 \mathrm{~kg}$ 인 80 두의 3 원교잡종 $($ Landrace $\times$ Yorkshire $\times$ Duroc)을 이용
하였다. 처리구는 일반 배합사료를 급여한 구 를 대조구로 하였으며, 일반 배합사료에 순도 95\% 글라이신 베타인(CTC 바이오, 한국)을 $0.2 \%$ 첨가한 구를 처리구 $1,0.4 \%$ 첨가한 구를 처리구 2 그리고 $0.6 \%$ 를 첨가한 구를 처리구 3으로 설정하여 40 일간 시험사료를 자유급이하 고 출하한 후 도축하여 등심부위를 채취하였 다. 채취한 등심은 랩으로 포장한 후 $4{ }^{\circ} \mathrm{C}$ 의 냉 장고에 놓고 13 일간 저장하면서 시험에 공시하 였다. 본 사양시험에 사용된 사료의 배합표는 Table 1과 같다.

Table 1. Formula of experiment $\operatorname{diet}(\%$, as fed basis)

\begin{tabular}{|c|c|}
\hline Item & Experiment diet \\
\hline \multicolumn{2}{|l|}{ Ingredients } \\
\hline Yellow corn & 69.25 \\
\hline Soybean meal & 14.68 \\
\hline Wheat bran & 5.65 \\
\hline Rapeseed meal & 3.00 \\
\hline Limestone & 1.00 \\
\hline Tricalcium phosphate & 0.84 \\
\hline Salt & 0.30 \\
\hline Vitamin* & 0.10 \\
\hline Mineral** & 0.10 \\
\hline Animal fat & 1.00 \\
\hline Molasses & 4.00 \\
\hline Lysine & 0.08 \\
\hline Antibiotics(CTC)*** & 0.00 \\
\hline Total & 100.00 \\
\hline \multicolumn{2}{|l|}{ Chemical Composition } \\
\hline DE(kcal/kg) & $3,300.00$ \\
\hline Crude protein(\%) & 14.00 \\
\hline Lysine(\%) & 0.75 \\
\hline \multicolumn{2}{|c|}{ 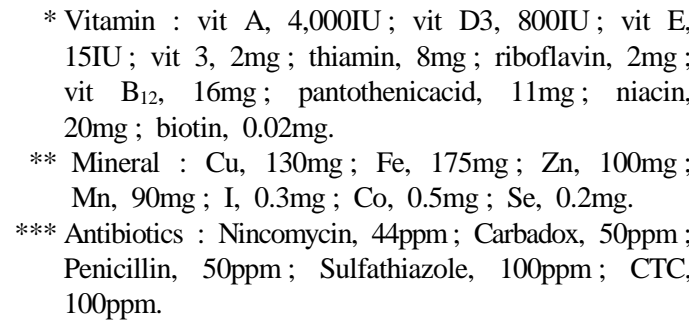 } \\
\hline
\end{tabular}




\section{2. 실험방법}

\section{(1) Glycine betaine 축적율}

시료 $1 \mathrm{~g}$ 을 증류수 $5 \mathrm{~m} \ell$ 과 함께 $20 \mathrm{~m} \ell$ 튜브 에 넣고 Polytron homogenizer(IKA T25basic, MALAYSIA)로 13,500 rpm에서 5초간 균질한 후, 5 분간 강하게 voltexing하고 원심분리기(Hanil, Union 5KR, Korea)에서 2,000g로 5 분간 원심분 리 하였다. 원심분리 후 샘플의 상층을 제거한 다음, 하층과 동일한 량의 dichloromethane을 넣 어 혼합한 후 원심분리기에서 $2000 \mathrm{~g}$ 로 5 분간 원심분리한 후 수양액 부분을 취하였다. 채취 된 시료 $5 \mu \ell$ 에 $25 \mu \ell$ 의 acetone과 2-naphthacyl trifluoromethanesulfonate을 첨가하여 혼합한 후 High performance lipuid chromatography(HPLC: Shimadzu, Japan) vial에 넣어 분석하였다. 이때 HPLC의 조건은 아래와 같았다.

\section{Column : C18 or Shodex NH2}

Mobile phase : acetonitrile/water $=50 / 50$

Flow rate : $1 \mathrm{~m} \ell / \mathrm{min}$

UV wave length for detection : at 194nm

(2) $\mathrm{pH}$

시료를 일정한 크기 $(3 \times 3 \times 3 \mathrm{~cm})$ 로 절단하고 $3 \mathrm{~mm}$ 플레이트로 쵸핑한 후 $50 \mathrm{~m} \ell$ 튜브에 시료 $3 g$ 과 증류수 $27 \mathrm{~m} \ell(1: 9)$ 를 함께 넣어 Polytron homogenizer로 13,500 rpm에서 5초간 균질하여 pH-meter(ORION 520A, USA)로 측정하였다.

\section{(3) 육색(Color)}

육색은 Minolta chromameter(Minolta CR 301, JAPAN)를 사용하여 동일한 시료표면을 5회 반 복하여 명도(lightness)를 나타내는 $\mathrm{L}^{*}$ 값, 적색도 (redness)를 나타내는 $\mathrm{a}^{*}$ 값과, 황색도(Yellowness) 를 나타내는 $\mathrm{b}^{*}$ 값을 측정하였다. 이때 표준색 은 $\mathrm{L}^{*}$ 값이 $89.2, \mathrm{a}^{*}$ 값이 $0.921, \mathrm{~b}^{*}$ 값이 0.783 인 표준색판을 사용하여 표준화한 후 측정하였 다.

\section{(4) 전단가(Shear force)}

전단력 측정은 고기 시료 $(10 \times 5 \times 5 \mathrm{~cm})$ 를 zipper bag에 넣고 $90^{\circ} \mathrm{C}$ 에서 30 분간 가열한 후 방
냉하여 직경 $1.27 \mathrm{~cm}$ 의 원통형 절편으로 만들어 cutting compression probe를 이용하여 Instron Universal Testing Machine(Model 100)으로 측정 하였다. 이때 기기의 조건은 아래와 같았다.

Load cell : $5 \mathrm{~kg}$

Range 50kg/10LB

Cross head speed : 100/min

Chart speed : 100/min

(5) 근절길이(Sarcomere length)

근절길이 측정은 Voyle(1971)의 방법을 기초 로 하여 시료를 일정한 크기 $(3 \times 3 \times 3 \mathrm{~cm})$ 로 자 른 후, 용액 $\mathrm{A}\left(0.1 \mathrm{M} \mathrm{KCl}+0.039 \mathrm{M} \quad \mathrm{H}_{3} \mathrm{BO}_{3}+\right.$ $5 \mathrm{mmM} \mathrm{EDTA}+2.5 \%$ Glutaraldehyde)에 넣고 냉 장실 $\left(2 \sim 4^{\circ} \mathrm{C}\right)$ 에서 2 시간 동안 방치한 다음 2시간 이 경과 후 용액 $\mathrm{B}\left(0.25 \mathrm{M} \mathrm{KCl}+0.29 \mathrm{M} \mathrm{H}_{3} \mathrm{BO}_{3}+\right.$ $5 \mathrm{mmM}$ EDTA + $2.5 \%$ Glutaraldehyde)에 넣고 냉장실 $\left(2 \sim 4^{\circ} \mathrm{C}\right)$ 에서 17 에서 19 시간동안 방치하 였다. 이후 시료를 근육의 결에 따라 잘게 절 단하고 용액 $\mathrm{B}$ 에 담겨있는 상태에서 균질한 다 음, 균질액을 몇 방울을 슬라이드 글라스 위에 떨어트린 후, 헬륨레온 레이져 광선을 비춰 얻 어지는 근절의 길이를 측정하였다. 이때 실제 근절길이를 산출하는 공식은 아래와 같았다.

$\mathrm{T}$ : 반지름, $\mathrm{D}$ : 헬륨레온 레이져와 슬라이드 글 라스의 높이

Sarcomere length

$$
=\left\{632.8 \times 10^{-3} \times \mathrm{D} \times \sqrt{(\mathrm{T} / \mathrm{D})^{2}}+1\right\} / \mathrm{T}
$$

(6) 지방산패도(TBARS : Thiobarbituric Acid Reactive Substances)

지방산화물의 측정은 Burge와 Aust(1978)의 방법을 기초로 하여 $50 \mathrm{~m} \ell$ test tube에 시료 $5 \mathrm{~g}$ 을 BHA 50ul와 증류수 $15 \mathrm{~m} \ell$ 를 가해 polytorn homogenizer로 $14,000 \mathrm{rpm}$ 에서 30초간 균질하였 으며, 균질액 $1 \mathrm{~m} \ell$ 를 $10 \mathrm{~m} \ell$ culture tube에 넣고 여기에 $2 \mathrm{~m} \ell \mathrm{TBA} / \mathrm{TCA}$ 혼합용액을 넣어 완전히 혼합한 다음, $90^{\circ} \mathrm{C}$ water bath에서 15 분간 열처 리한 후 10 분간 냉각시켜 $3,000 \mathrm{rpm}$ 에서 10 분 간 원심분리 하였다. 원심분리한 시료의 상층을 회수하여 spectrophotometer 531nm에서 흡광도를 
측정했다. 이때 TBARS값을 측정하는 공식은 아래와 같았다.

$$
\text { TBARS }=\text { AbsorbanceO.D. } \times 5.88
$$

(7) 지방산 조성(Fatty acid composition)

고기 시료를 Folch 등(1957)의 방법을 이용하 여 조지방을 추출하고, 추출된 조지방 시료에 chloroform $1 \mathrm{~m} \ell$ 을 넣어 녹인 다음, 이중 $100 \mu \ell$ 를 취하여 $20 \mathrm{~m} \ell$ tube에 넣었다. 이때 $1 \mathrm{~m} \ell$ 의 methylation(methanolic-HCl-3N) 시약을 넣고 water bath에서 $60^{\circ} \mathrm{C}$ 로 40 분간 반응시켰다. 반응이 끝난 후 방냉하여 hexane $3 \mathrm{~m} \ell$ 과 증류수 $8 \mathrm{~m} \ell$ 을 넣고 강하게 혼합 하였고, 혼합이 끝난 시료는 24 시간 방치하여 층 분리시키고 층 분리가 끝 난 상층액 $1 \mathrm{~m} \ell$ 을 Gas chromatography로 분석하 였다. 지방산 분석시 Gas chromatography의 조 건은 Table 2와 같았다.

Table 2. GC conditions for analysis of fatty acid compositions

\begin{tabular}{ll}
\hline Item & \multicolumn{1}{c}{ Conditions } \\
\hline \hline Instrument & $\begin{array}{l}\text { Hewlett Packard } 6890 \mathrm{Gas} \\
\text { chromatography } \\
\text { Column }\end{array}$ \\
& $\begin{array}{l}5 \% \text { Phenyl methyl siloxane } \\
30 \mathrm{~m} \times 320 \mu \mathrm{m}\end{array}$ \\
Temperature program & $5^{\circ} \mathrm{C} / \mathrm{min}$ \\
Detector & Flame Ionization Detector \\
& $(\mathrm{FID})$ \\
Initial temperature & $50{ }^{\circ} \mathrm{C}$ \\
Initial time & $1 \mathrm{~min}$ \\
Final temperature & $200{ }^{\circ} \mathrm{C}$ \\
Final time & $40 \mathrm{~min}$ \\
Injector temperature & $270{ }^{\circ} \mathrm{C}$ \\
Dector temperature & $270{ }^{\circ} \mathrm{C}$ \\
Carrier gas & $\mathrm{He}$ \\
Split ratio & $90: 1$ \\
\hline
\end{tabular}

(8) 관능검사(Sensory evaluation)

관능적 특성검사를 위해 관능검사 요원 50 명 을 선별하여 저장기간에 따른 관능적 평가를 실시하였다. 관능평가를 실시하기 전 평가항목
에 대한 방법을 설명 한 후 무작위로 배열시킨 뒤 실시하였다. 시료는 심부 온도 $70^{\circ} \mathrm{C}$ 까지 oven에서 가열하고 겉 부분을 제거한 후 일정 한 모양으로 잘라서 척도묘사법으로 관능검사 를 실시하였다.

신선육은(fresh meat)은 육향(aroma), 육색(color), 이취(off-flavor), 육즙참출정도(purge loss), 기호 도(acceptability)를 조사하였고, 조리육(cooked meat) 은 육색(color), 육향(aroma), 풍미(flavor), 이취 (off-flavor), 다즙성(juiciness), 연도(tenderness), 기호성(acceptability)을 각각 조사하였다.

\section{3. 통계방법}

이상의 실험에서 얻어진 성적을 $\mathrm{SAS} / \mathrm{PC}+$ (SAS, 1996) system을 이용하여 분산분석 및 Duncan의 다중검정을 실시하였다.

\section{III 결과 및 고찰}

\section{Glycine betaine의 축적율}

글라이신 베타인 급여가 돈육 등심의 글라이 신 베타인 축적율에 미치는 영향을 Fig. 1에 나 타내었다. 글라이신 베타인의 축적율은 글라이 신 베타인 급여율이 높을수록 높게 나타났는데, 대조구는 $0.001 \mathrm{mg}$ 수준을 나타내었고, $0.2 \%$ 글 라이신 베타인 급여구는 $0.159 \mathrm{mg}, 0.4 \%$ 글라이신

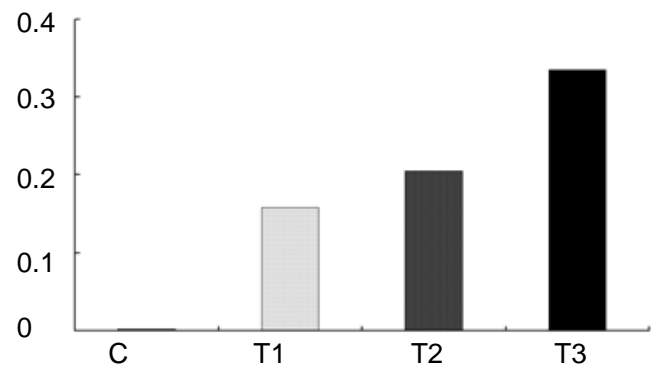

Fig. 1. Effect of dietary glycine betaine on glycine bataine accumulation ratio in pork loin during storage.

${ }^{1)} \mathrm{C}$ : commercial diet, $\mathrm{T} 1$ : containing $0.2 \%$ glycine betaine, T2: containing $0.4 \%$ glycine betaine, T3: containing $0.6 \%$ glycine betaine. 
베타인 급여구는 $0.205 \mathrm{mg}$ 그리고 $0.6 \%$ 글라이신 베타인 급여구는 $0.335 \mathrm{mg} / \mathrm{g}$ 의 축적율을 나타내었 다. de Zwart 등(2003)은 글라이신 베타인은 많은 종류의 식물이나 동물체의 근육 내에 존재하는 데, 이는 음식물의 섭취를 통해 흡수되거나 혹은 간에서 콜린의 대사작용을 통하여 합성된다고 보 고하였다. Matthews 등(2001b)은 글라이신 베타인 의 급여에 의해 돈육 등심 내 글라이신 베타인이 축적된다고 보고하였다. 본 연구에서는 글라이신 베타인을 급여하지 않은 대조구에서도 미량의 글 라이신 베타인이 축적되었는데 이는 사료 내에 미량의 글라이신 베타인이 함유된 결과로 사료된 다. 또한 글라이신 베타인이 함유된 사료를 급여 시 돼지 등심 내 글라이신 베타인이 축적되며, 급여량이 증가할수록 글라이신 베타인의 축적율 을 증가하는 것으로 나타났다.

\section{Glycine betaine의 급여가 $\mathrm{pH}$ 의 변화에 미 치는 영향}

글라이신 베타인 급여가 저장기간 중 돈육 등심의 $\mathrm{pH}$ 에 미치는 영향을 Table 3에 나타내 었다. $0.4 \%$ 글라이신 베타인 급여구는 저장기 간의 증가에 따라 등심육의 $\mathrm{pH}$ 가 유의적으로 $(\mathrm{P}<0.05)$ 증가하였으나, 다른 처리구는 저장기 간의 경과에 따라 유의적인 차이를 나타내지 않았다. 저장 1 일부터 9 일까지는 글라이신 베 타인 급여수준에 따른 차이를 나타내지 않았으 나, 저장 13 일에는 글라이신 베타인 급여구가 대조구에 비교해 유의적으로 $(\mathrm{P}<0.05)$ 높게 나
타났다. Matthews 등(2001a)은 글라이신 베타인 의 급여에 의해 돈육의 $\mathrm{pHu}$ 가 증가하였는데, 이는 글라이신 베타인이 근육내 젖산의 대사에 영향을 미치기 때문이라고 하였다. 또한 Warren 등(1999)은 글라이신 베타인 급여에 의해 혈장 내 lactate의 농도가 낮아진다고 보고하여 이러 한 결과를 뒷받침해주고 있다. 사후초기 근육 의 $\mathrm{pH}$ 저하속도는 스트레스(Apple 등, 1995), 전 기자극(Chrystall 등, 1984) 및 냉각온도(Greaser, 1986) 등과 같은 여러 가지 요인들에 의해 영 향을 받는다. 또한 사후 몇 시간 동안 일어나 는 대사는 육질을 결정하는 주요한 인자로 작 용하는데(Kauffman과 Marsh, 1987), 식육의 최 종 $\mathrm{pH}$ 가 높을 경우 연도가 증진되고(Greaser, 1986), 최종 $\mathrm{pH}$ 가 높은 근육의 경우 빠른 대사 가 이루어져 칼슘 이온의 방출도 빠르게 진행 되고, calpain들의 활성으로 인해 연도가 향상되 는 것으로 보고 되어지고 있다(Etherington 등, 1990). 또한 젖산의 축적에 의한 $\mathrm{pH}$ 의 감소는 단백질의 변성을 가져오고 이러한 단백질 변성 은 보수력을 저하시키는 원인이 되며(Hedrick 등, 1994), Brown과 Mebine(1969)은 낮은 $\mathrm{pH}$ 에 서 마이오 글로빈의 산화가 잘 일어난다고 보 고하였다. 본 실험 결과 저장초기에는 글라이 신 베타인 급여에 의한 차이가 나타나지 않았 으나, 저장 말기에는 글라이신 베타인 급여구 가 높은 $\mathrm{pH}$ 수준을 나타내었다. 따라서 글라이 신 베타인의 급여는 $\mathrm{pH}$ 감소를 억제한 결과 대조구에 비교해 저장말기의 육색 및 보수력을 증가시킬 수 있을 것으로 사료된다.

Table 3. Effect of dietary glycine betaine on $\mathrm{pH}$ in pork loin during storage

\begin{tabular}{ccccc}
\hline \multirow{2}{*}{ Treatments } & \multicolumn{5}{c}{ Storage period (days) } \\
\cline { 2 - 5 } & 1 & 5 & 9 & 13 \\
\hline \hline C & $5.50 \pm 0.09$ & $5.52 \pm 0.10$ & $5.56 \pm 0.07$ & $5.51 \pm 0.07^{\mathrm{C}}$ \\
T1 & $5.50 \pm 0.08$ & $5.50 \pm 0.01$ & $5.56 \pm 0.02$ & $5.56 \pm 0.03^{\mathrm{A}}$ \\
T2 & $5.47 \pm 0.04^{\mathrm{b}}$ & $5.52 \pm 0.04^{\mathrm{ab}}$ & $5.58 \pm 0.05^{\mathrm{a}}$ & $5.56 \pm 0.01^{\mathrm{Aa}}$ \\
T3 & $5.52 \pm 0.06$ & $5.54 \pm 0.07$ & $5.59 \pm 0.05$ & $5.61 \pm 0.04^{\mathrm{A}}$ \\
\hline
\end{tabular}

1) $\mathrm{C}$ : commercial diet, $\mathrm{T} 1$ : containing $0.2 \%$ glycine betaine, $\mathrm{T} 2:$ containing $0.4 \%$ glycine betaine, $\mathrm{T} 3:$ containing $0.6 \%$ glycine betaine.

${ }_{A, B, C, D}$ Means in the same column with different letters are different $(\mathrm{P}<0.05)$.

a,b,c,d Means in the same row with different letters are different $(\mathrm{P}<0.05)$. 
Table 4. Effect of dietary glycine betaine on meat color in pork loin during storage

\begin{tabular}{|c|c|c|c|c|c|}
\hline \multirow{2}{*}{\multicolumn{2}{|c|}{ Treatments }} & \multicolumn{4}{|c|}{ Storage period (days) } \\
\hline & & 1 & 5 & 9 & 13 \\
\hline \multirow{4}{*}{$\mathrm{L}^{*}$} & $\mathrm{C}$ & $49.49 \pm 4.00^{\mathrm{b}}$ & $47.02 \pm 2.09^{\mathrm{b}}$ & $49.00 \pm 3.91^{\mathrm{b}}$ & $56.99 \pm 2.25^{\mathrm{a}}$ \\
\hline & $\mathrm{T} 1$ & $49.25 \pm 3.79^{b}$ & $49.84 \pm 2.60^{\mathrm{b}}$ & $47.22 \pm 2.21^{\mathrm{b}}$ & $55.88 \pm 2.29^{\mathrm{a}}$ \\
\hline & $\mathrm{T} 2$ & $47.09 \pm 2.93^{\mathrm{b}}$ & $47.07 \pm 2.16^{\mathrm{b}}$ & $47.01 \pm 2.45^{\mathrm{b}}$ & $56.81 \pm 2.34^{\mathrm{a}}$ \\
\hline & $\mathrm{T} 3$ & $47.88 \pm 2.55^{\mathrm{b}}$ & $49.47 \pm 3.45^{\mathrm{b}}$ & $47.50 \pm 3.10^{\mathrm{b}}$ & $55.88 \pm 1.39^{\mathrm{a}}$ \\
\hline \multirow{4}{*}{$a^{*}$} & $\mathrm{C}$ & $12.69 \pm 1.93^{\mathrm{Bb}}$ & $17.05 \pm 1.93^{\mathrm{ABa}}$ & $16.80 \pm 1.63^{\mathrm{Aa}}$ & $7.94 \pm 1.11^{\mathrm{c}}$ \\
\hline & $\mathrm{T} 1$ & $12.75 \pm 1.27^{\mathrm{Bb}}$ & $16.39 \pm 2.26^{\mathrm{ABa}}$ & $16.39 \pm 2.26^{\mathrm{Aa}}$ & $7.80 \pm 0.93^{c}$ \\
\hline & $\mathrm{T} 2$ & $15.90 \pm 3.16^{\mathrm{Aab}}$ & $18.00 \pm 3.85^{\mathrm{Aa}}$ & $13.69 \pm 1.59^{\mathrm{Bb}}$ & $7.07 \pm 0.73^{\mathrm{c}}$ \\
\hline & $\mathrm{T} 3$ & $15.12 \pm 3.12^{\mathrm{Aa}}$ & $14.94 \pm 2.34^{\mathrm{Ba}}$ & $15.75 \pm 2.04^{\mathrm{ABa}}$ & $7.52 \pm 1.13^{\mathrm{b}}$ \\
\hline \multirow{4}{*}{$\mathrm{b}^{*}$} & $\mathrm{C}$ & $5.27 \pm 1.56^{\mathrm{b}}$ & $7.41 \pm 1.10^{\mathrm{a}}$ & $6.82 \pm 1.23^{\mathrm{ABa}}$ & $7.45 \pm 1.15^{\mathrm{Aa}}$ \\
\hline & $\mathrm{T} 1$ & $4.45 \pm 1.11^{\mathrm{b}}$ & $7.54 \pm 1.35^{\mathrm{a}}$ & $7.54 \pm 1.35^{\mathrm{Aa}}$ & $6.61 \pm 1.09^{\mathrm{ABa}}$ \\
\hline & $\mathrm{T} 2$ & $4.98 \pm 2.07^{\mathrm{b}}$ & $7.29 \pm 2.65^{\mathrm{a}}$ & $5.42 \pm 1.30^{\mathrm{Bb}}$ & $6.63 \pm 1.07^{\mathrm{ABab}}$ \\
\hline & T3 & $4.79 \pm 2.08^{\mathrm{b}}$ & $7.03 \pm 1.81^{\mathrm{a}}$ & $5.72 \pm 1.59^{\mathrm{Bab}}$ & $5.87 \pm 1.31^{\mathrm{Bab}}$ \\
\hline
\end{tabular}

3. Glycine betaine의 급여가 육색의 변화에 미치는 영향

글라이신 베타인 급여에 의한 돈육등심의 육 색 변화를 보면 명도값 $\mathrm{L}^{*}$ 는 저장기간의 증가에 의해 모든 처리구에서 유의적으로 $(\mathrm{P}<0.05)$ 증가 하였다. 그러나 글라이신 베타인 급여 수준에 의 한 $\mathrm{L}^{*}$ 는 유의적인 차이를 나타내지 않았다. Matthews 등(2001b)은 $0.250 \%$ 의 글라이신 베타인 급여에 의해 뒷다리 육은 $\mathrm{CIE} \mathrm{L}^{*}$ 값이 감소하였 으나, 등심육은 글라이신 베타인 급여에 의한 CIE L* 값의 변화가 없었다고 보고하여 본 연구 와 유사한 경향을 나타내었다. 적색도 $\mathrm{a}$ *는 모든 처리구에서 저장기간이 경과할수록 유의적으로 $(\mathrm{P}$ $<0.05)$ 감소하는 경향을 나타내었다. 저장 기간 별 적색도의 변화를 보면 저장 5 일까지는 $0.4 \%$ 와 $0.6 \%$ 급여구가 대조구와 $0.2 \%$ 급여구에 비교 해 유의적으로 높은 적색도를 나타내었으나, 저 장 9일 이후에는 글라이신 베타인 급여에 의해 주목할만한 적색도의 변화를 나타내지 않았다. 황색도 $\mathrm{b}^{*}$ 는 모든 처리구에서 저장기간의 경과에 의해 유의적으로 $(\mathrm{P}<0.05)$ 증가하는 경향을 나타
내었다. 저장 1 일부터 5 일까지는 처리구간의 $\mathrm{b}^{*}$ 의 변화가 없었으나, 저장 9 일에는 $0.4 \%$ 와 $0.6 \%$ 글라이신 베타인 급여구가 대조구와 $0.2 \%$ 글라 이신 베타인 급여구에 비교해 유의적으로 $(\mathrm{P}<$ 0.05 ) 낮게 나타났다. 또한 저장 13 일에는 $0.6 \%$ 급여구가 가장 낮은 $(\mathrm{P}<0.05) \mathrm{b}^{*}$ 값을 나타내었 다. 육색은 소비자가 식육을 구매하는 가장 중요 한 기준이 되므로(Zhu와 Brewer, 1998), 육의 품 질에 중요한 요소가 된다. 이러한 육색은 저장기 간이 경과할수록 메트마이오글로빈의 형성율이 증가하기 때문에 육색이 퇴색되는데(Ledward와 Macfarlane, 1971), 저장기간 동안 빛의 노출은 육 색 변질에 영향을 미치며(Zhu와 Brewer, 1998), 어두운 곳에 있는 식육보다는 밝은 곳에 있는 식 육이 메트마이오글로빈이 더 많이 축적된다 (Lawrie, 1991). Matthews 등(1998)은 0.125\%의 글 라이신 베타인 급여에 의해 돈육의 육색이 저하 되었다고 보고하였는데 본 연구에서는 명도값 $\mathrm{L}^{*}$ 와 적색도 $\mathrm{a}^{*}$ 는 글라이신 베타인 급여에 의한 주 목할만한 차이를 나타내지는 않았으나 황색도 $b^{*}$ 는 글라이신 베타인 급여 수준이 높은구가 저장 말기에 낮게 나타났다. 


\section{Glycine betaine의 급여가 전단력에 미치} 는 영향

글라이신 베타인의 급여가 저장기간중 돈육 등심의 전단력에 미치는 영향을 Table 5에 나타 내었다. 저장기간의 경과에 따라 모든 처리구의 전단가는 유의적으로 $(\mathrm{P}<0.05)$ 감소하는 경향을 나타내었으며, 처리구간의 전단력 차이에서는 글라이신 베타인 급여구가 대조구에 비교해 유 의적으로 $(\mathrm{P}<0.05)$ 높은 전단력을 나타내었다. 또한 저장 9 일까지는 $0.4 \%$ 글라이신 베타인 급 여구가 가장 높은 $(\mathrm{P}<0.05)$ 전단력을 나타내었으 며, 저장 13 일에는 $0.2 \%$ 글라이신 베타인 급여 구가 유의적으로 $(\mathrm{P}<0.05)$ 가장 높은 전단력을 나타내었다. Geesink 등(1995)은 $\mathrm{pH}$ 와 온도 감소 율은 사후 1 일에서 전단가를 결정하는 중요한 영향을 미친다고 보고하였으며, 전단가는 식육 의 연도를 결정하는 중요한 요인이 된다고 보고 하였다. Smulders 등(1990)은 사후 3시간에 $\mathrm{pH}$ 를 이용한 근절길이와 전단가와의 관련성에서 느린 해당작용 $(\mathrm{pH} 3>6.3)$ 에서 근절길이와 관능적 연 도는 $\mathrm{r}=0.84$ 로 높은 관련성이 있다고 보고하였 다. O'Halloran 등(1997)은 사후 해당작용이 빠른 등심근육이 관능적, 조직적 특성에서 연도가 좋 게 평가되었고, 유의적으로 낮은 전단가를 보였 으며, 사후 2 일에서 해당작용이 느린 등심근육 이 더 짧은 근절길이를 가졌다고 보고하였다. Matthews 등 (2001b)은 글라이신 베타인 급여에 의해 돈육의 전단력은 변화가 없었다고 보고하 였으며, $0.125 \%$ 의 글라이신 베타인 급여가 돈육
의 상강도나 경도에 영향을 미치지 않는다고 보 고하였다(Matthew 등, 1998). 몇몇 연구(Campbell 등, 1997; Casarin 등, 1997; Cromwell 등, 1999) 에서 글라이신 베타인 급여에 의해 계육의 단백 질 함량이 높아졌으며, 돈육의 지방 함량은 줄 고 적육의 함량이 증가한다고 보고하였는데, 본 연구결과 글라이신 베타인의 급여는 돈육 등심 의 단백질 함량을 증가시킨 결과 전단력이 높게 나타난 것으로 사료된다.

\section{Glycine betaine의 급여가 근절길이에 미 치는 영향}

글라이신 베타인 급여가 저장기간중 돈육 등 심의 근절길이 변화에 미치는 영향을 Table 6 에 나타내었다. 모든 처리구에서 저장기간이 경과할수록 근절길이는 증가하는 경향을 나타 내었으며, 처리구간에 근절의 길이는 $0.6 \%$ 글 라이신 베타인 급여구가 전 저장기간동안 가장 짧은 $(\mathrm{P}<0.05)$ 근절길이를 나타내었으며, 대조 구의 근절길이는 전 저장기간동안 가장 길게 나타났다. 사후 근절길이의 감소는 육의 질김 을 증가시키는 중요한 원인이다(Herring 등, 1965). 이러한 육의 질김은 근원섬유 구조를 붕 괴시키는 단백질 분해효소의 활성에 영향을 미 치는 $\mathrm{pH}$ 의 직접적인 효과에 의해 주로 영향을 받지만(Watanabe 등, 1996), 비 효소적 기작으로 는 근원섬유 단백질에 직접적으로 영향을 미치 는 $\mathrm{Ca}^{2+}$ 의 효과(Takahashi 등, 1987) 등이 있다. Tornberg(1996)는 생육에서 근섬유의 수축은 근

Table 5. Effect of dietary glycine betaine on shear force iin pork loin during storage

\begin{tabular}{|c|c|c|c|c|}
\hline \multirow{2}{*}{ Treatments $^{1)}$} & \multicolumn{4}{|c|}{ Storage periods } \\
\hline & 1 & 5 & 9 & 13 \\
\hline & \multicolumn{4}{|c|}{ 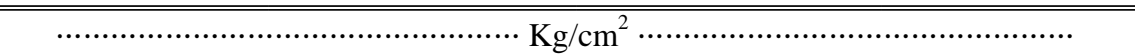 } \\
\hline $\mathrm{C}$ & $3.13 \pm 0.67^{\mathrm{Da}}$ & $3.00 \pm 0.75^{\mathrm{BCa}}$ & $2.93 \pm 0.67^{\mathrm{Ba}}$ & $1.70 \pm 0.41^{\mathrm{Cb}}$ \\
\hline $\mathrm{T} 1$ & $3.65 \pm 0.40^{\mathrm{Ca}}$ & $2.87 \pm 0.55^{\mathrm{Cb}}$ & $2.63 \pm 0.52^{\mathrm{Cc}}$ & $2.28 \pm 0.60^{\mathrm{Ad}}$ \\
\hline $\mathrm{T} 2$ & $4.43 \pm 0.66^{\mathrm{Aa}}$ & $3.60 \pm 081^{\mathrm{Ab}}$ & $3.34 \pm 0.51^{\mathrm{Ab}}$ & $2.07 \pm 0.65^{\mathrm{ABc}}$ \\
\hline $\mathrm{T} 3$ & $3.98 \pm 0.84^{\mathrm{Ba}}$ & $3.21 \pm 0.46^{\mathrm{Bb}}$ & $2.71 \pm 0.54^{\mathrm{BCc}}$ & $1.98 \pm 0.50^{\mathrm{Bd}}$ \\
\hline
\end{tabular}


Table 6. Effect of dietary glycine betaine on sarcomere length in pork loin during storage

\begin{tabular}{|c|c|c|c|c|}
\hline \multirow{2}{*}{ Treatments ${ }^{1)}$} & \multicolumn{4}{|c|}{ Storage periods } \\
\hline & 1 & 5 & 9 & 13 \\
\hline & $\cdots$ & . & …................. & ................. \\
\hline $\mathrm{C}$ & $0.75 \pm 0.05^{\mathrm{Ac}}$ & $0.83 \pm 0.04^{\mathrm{Ab}}$ & $0.87 \pm 0.08^{\mathrm{Ab}}$ & $0.94 \pm 0.08^{\mathrm{ABa}}$ \\
\hline $\mathrm{T} 1$ & $0.67 \pm 0.12^{\mathrm{ABb}}$ & $0.70 \pm 0.11^{\mathrm{Bb}}$ & $0.78 \pm 0.16^{\mathrm{Bab}}$ & $0.83 \pm 0.16^{\mathrm{BCa}}$ \\
\hline $\mathrm{T} 2$ & $0.73 \pm 0.04^{\mathrm{Ac}}$ & $0.85 \pm 0.07^{\mathrm{Ab}}$ & $0.91 \pm 0.12^{\mathrm{Aab}}$ & $1.00 \pm 0.22^{\mathrm{Aa}}$ \\
\hline T3 & $0.61 \pm 0.17^{\mathrm{Bc}}$ & $0.65 \pm 0.08^{\mathrm{Bbc}}$ & $0.73 \pm 0.11^{\mathrm{Bab}}$ & $0.80 \pm 0.11^{\mathrm{Ca}}$ \\
\hline
\end{tabular}

1) $\mathrm{C}$ : commercial diet, $\mathrm{T} 1$ : containing $0.2 \%$ glycine betaine, $\mathrm{T} 2$ : containing $0.4 \%$ glycine betaine, T3: containing $0.6 \%$ glycine betaine.

$\mathrm{A}, \mathrm{B}, \mathrm{C}, \mathrm{D}$ Means in the same column with different letters are different $(\mathrm{P}<0.05)$.

a,b,c,d Means in the same row with different letters are $\operatorname{different}(\mathrm{P}<0.05)$.

절이 짧아짐에 따라 증가하였고, 근절이 짧아 질수록 전단가는 높게 나타났다고 보고하였다. 본 연구결과 글라이신 베타인의 급여는 돈육 등심의 근절길이를 감소시키는 것으로 나타났으 며, 이러한 근절길이의 감소는 전단가의 증가를 가져왔을 것으로 사료된다. 글라이신 베타인 급 여에 의한 등심근의 근절길이 감소에 대한 정확 한 기작은 밝혀지지 않고 있으나, Silva(1999)는 사후 근육의 해당작용은 온도와 $\mathrm{pH}$ 에 미치는 효과와 그로 인한 단백질 분해효소의 활성에 미 치는 영향으로 육의 연도에 주요한 결정인자로 작용한다고 보고하였다. 또한 본 연구에서 글라 이신 베타인의 급여는 저장 말기 돈육등심의 $\mathrm{pH}$ 를 증가시키는 것으로 나타났으나 전단가는
낮아지는 경향을 나타냄으로써 $\mathrm{pH}$ 증가에 따른 전단가의 변화가 다른 연구와 일치하지 않는 경 향을 나타내었다. 그러므로 글라이신 베타인의 급여가 $\mathrm{pH}$ 와 근절길이의 변화 및 전단가의 변 화에 미치는 영향에 관한 더 많은 연구가 필요 할 것으로 사료된다.

\section{Glycine betaine의 급여가 지방산화 및 지방산 조성에 미치는 영향}

글라이신 베타인 급여가 저장기간동안 돈육 등심의 지방산화에 미치는 영향을 Table 7에 나타내었다. 저장기간이 경과할수록 모든 처리 구의 지방산패도는 유의적으로 $(\mathrm{P}<0.05)$ 증가하

Table 7. Effect of dietary glycine betaine on TBARS in pork loin during storage

\begin{tabular}{|c|c|c|c|c|}
\hline \multirow{2}{*}{ Treatments } & \multicolumn{4}{|c|}{ Storage period(days) } \\
\hline & 1 & 5 & 9 & 13 \\
\hline \multicolumn{5}{|c|}{. } \\
\hline $\mathrm{C}$ & $0.20 \pm 0.02^{c}$ & $0.21 \pm 0.01^{\mathrm{bc}}$ & $0.22 \pm 0.01^{\mathrm{b}}$ & $0.24 \pm 0.01^{\mathrm{a}}$ \\
\hline $\mathrm{T} 1$ & $0.20 \pm 0.02^{c}$ & $0.20 \pm 0.01^{\mathrm{c}}$ & $0.21 \pm 0.03^{\mathrm{b}}$ & $0.24 \pm 0.05^{\mathrm{a}}$ \\
\hline $\mathrm{T} 2$ & $0.19 \pm 0.06^{\mathrm{b}}$ & $0.20 \pm 0.02^{\mathrm{b}}$ & $0.22 \pm 0.03^{\mathrm{ab}}$ & $0.23 \pm 0.04^{\mathrm{a}}$ \\
\hline T3 & $0.20 \pm 0.03^{c}$ & $0.20 \pm 0.01^{\mathrm{c}}$ & $0.22 \pm 0.03^{b}$ & $0.24 \pm 0.02^{\mathrm{a}}$ \\
\hline \multicolumn{5}{|c|}{$\begin{array}{l}\text { C: commercial diet, } \mathrm{T} 1: \text { containing } 0.2 \% \text { glycine betaine, } \mathrm{T} 2: \text { containing } 0.4 \% \text { glycine betaine, } \mathrm{T} 3: \text { contair } \\
0.6 \% \text { glycine betaine. } \\
\mathrm{A} \text { (1), MA : Malondialdyhyde. }\end{array}$} \\
\hline
\end{tabular}


Table 8. Effect of dietary glycine betaine on fatty acid in pork loin during storage

\begin{tabular}{lcccc}
\hline \multirow{2}{*}{ Treatments ${ }^{1)}$} & \multicolumn{4}{c}{ Fatty acid (\%) } \\
\cline { 2 - 5 } & $\mathrm{C}$ & $\mathrm{T} 1$ & $\mathrm{~T} 2$ & $\mathrm{~T} 3$ \\
\hline \hline Myristic acid $(14: 0)$ & $1.55^{\mathrm{A}}$ & $1.35^{\mathrm{B}}$ & $1.44^{\mathrm{AB}}$ & $1.40^{\mathrm{AB}}$ \\
Palmitic acid $(16: 1)$ & $20.07^{\mathrm{AB}}$ & $19.57^{\mathrm{B}}$ & $21.54^{\mathrm{A}}$ & $20.63^{\mathrm{AB}}$ \\
Palmitoleic acid $(16: 0)$ & $3.15^{\mathrm{B}}$ & $2.96^{\mathrm{C}}$ & $3.42^{\mathrm{A}}$ & $2.57^{\mathrm{D}}$ \\
Stearic acid $(18: 0)$ & $13.15^{\mathrm{B}}$ & $13.94^{\mathrm{B}}$ & $13.69^{\mathrm{B}}$ & $15.25^{\mathrm{A}}$ \\
Oliec acid $(18: 1)$ & 43.56 & 43.90 & 43.75 & 43.37 \\
Linoleic acid $(18: 2)$ & $14.96^{\mathrm{A}}$ & $14.45^{\mathrm{AB}}$ & $12.56^{\mathrm{C}}$ & $13.09^{\mathrm{B}}$ \\
Linolenic acid $(18: 3)$ & 1.36 & 1.42 & 1.49 & 1.47 \\
Archidonic acid $(20: 4)$ & 2.20 & 2.41 & 2.11 & 2.22 \\
SFA/USFA & $34.77 / 65.23$ & $34.86 / 65.14$ & $36.67 / 63.33$ & $37.28 / 62.72$ \\
\hline
\end{tabular}

${ }^{1)} \mathrm{C}$ : commercial diet, $\mathrm{T} 1$ : containing $0.2 \%$ glycine betaine, $\mathrm{T} 2:$ containing $0.4 \%$ glycine betaine, $\mathrm{T} 3:$ containing $0.6 \%$ glycine betaine.

2) SFA/USFA: saturated fatty acid/unsaturated fatty acid.

$\mathrm{A}, \mathrm{B}, \mathrm{C}, \mathrm{D}, \mathrm{E}, \mathrm{F}$ Means in the same row with different letters are $\operatorname{different}(\mathrm{P}<0.05)$.

였으나, 처리구간의 지방산패도는 전 저장기간 동안 유의적인 차이를 나타내지 않았다. 지방 의 산화는 육색소의 산화를 야기하여 육색을 저하시키고, 이취를 발생시키며 식육의 품질을 저하시킨다. 본 연구결과 돼지에 있어 글라이 신 베타인 급여는 돈육 등심의 지방산화 억제 에는 영향을 미치지 않는 것으로 나타났다.

글라이신 베타인의 급여가 돈육 등심내 지방 산 조성에 미치는 영향을 조사한 결과(Table 8) 글라이신 베타인의 급여에 의해 불포화지방산 의 함량은 감소하고 포화지방산의 함량은 증가 하는 결과를 나타내었다. 특히 linoleic acid와 myristic acid는 글라이신 베타인의 급여 수준이 높을수록 감소하는 $(\mathrm{P}<0.05)$ 경향을 나타내었 다. 그러나 stearic acid는 글라이신 베타인 급여 수준이 높은 $0.6 \%$ 급여구에서 유의적으로 $(\mathrm{P}<$ 0.05) 높게 나타났다. Fernandez 등(1998)은 글라 이신 베타인 급여에 의해 단가 불포화 지방산 의 함량은 증가하였고, 다가 불포화 지방산의 함량은 감소하였다고 보고하여 본 연구와는 다 소 차이를 보였다. 지방산의 조성은 식육의 품 질에 크게 작용하는데, 그 이유는 지방산의 조 성에 따라 지방의 경도나 응집성에 차이가 나 고, 불포화 지방산과 포화지방산의 비율에 따
라 식육의 저장성에 영향을 받기 때문이다 (Wood 등, 2003). 또한 포화지방산의 증가는 지 방의 경도를 증가시키는 작용을 하며, 본 연구 에서 글라이신 베타인의 급여에 의한 포화지방 산의 증가는 지방 함량이 낮은 등심의 연도에 는 크게 영향을 미치지 않았을것으로 사료된다.

\section{Glycine betaine의 급여가 관능검사에 미 치는 영향}

글라이신 베타인의 급여가 저장기간동안 돈 육 등심의 관능적 특성에 미치는 영향을 Table 9에 나타내었다. 신선육의 관능검사에서 육색 은 저장 1 일차에 글라이신 베타인 급여구가 대 조구에 비교해 유의적으로 $(\mathrm{P}<0.05)$ 높게 나타 났으나 저장기간이 경과한 이후에는 처리구간 의 차이는 나타나지 않았다. 그러나 신선육의 육향과 전체적인 기호도 및 가열육 관능검사시 육향, 연도, 다즙성 그리고 기호도에서는 처리 구간의 주목할만한 차이를 나타내지 않았다. Øverland 등(1999)은 1\%의 글라이신 베타인 급 여가 돈육의 관능적 특성에는 아무런 영향을 미치지 않는다고 보고하여 본 연구와 유사한 결과를 보여주었다. 본 연구결과 글라이신 베 
Table 9. Effect of dietary glycine betaine on sensory evaluation in pork loin during storage

\begin{tabular}{|c|c|c|c|c|c|}
\hline \multirow{2}{*}{\multicolumn{2}{|c|}{ Treatments ${ }^{1)}$}} & \multicolumn{4}{|c|}{ Storage periods } \\
\hline & & 1 & 5 & 9 & 13 \\
\hline \multirow{4}{*}{ Fresh meat color } & $\mathrm{C}$ & $3.3^{\mathrm{C}}$ & 3.5 & 3.4 & 3.3 \\
\hline & $\mathrm{T} 1$ & $3.8^{\mathrm{A}}$ & 3.6 & 3.5 & 3.4 \\
\hline & $\mathrm{T} 2$ & $3.5^{\mathrm{B}}$ & 3.7 & 3.6 & 3.5 \\
\hline & T3 & $3.9^{\mathrm{A}}$ & 3.6 & 3.4 & 3.4 \\
\hline \multirow{4}{*}{$\begin{array}{l}\text { Fresh meat } \\
\text { flavor }\end{array}$} & $\mathrm{C}$ & 4.2 & 4.5 & 4.5 & 4.2 \\
\hline & $\mathrm{T} 1$ & 4.1 & 4.6 & 4.4 & 4.1 \\
\hline & $\mathrm{T} 2$ & 4.3 & 4.6 & 4.5 & 4.3 \\
\hline & T3 & $4.4^{c}$ & $4.8^{\mathrm{a}}$ & $4.6 \mathrm{~b}$ & $4.3^{c}$ \\
\hline \multirow{4}{*}{$\begin{array}{l}\text { Fresh meat } \\
\text { Acceptability }\end{array}$} & $\mathrm{C}$ & $4.3^{\mathrm{bc}}$ & $4.4^{\mathrm{b}}$ & $4.6^{\mathrm{a}}$ & $4.2^{c}$ \\
\hline & $\mathrm{T} 1$ & 4.4 & 4.4 & 4.5 & 4.2 \\
\hline & $\mathrm{T} 2$ & 4.3 & 4.4 & 4.5 & 4.3 \\
\hline & T3 & 4.3 & 4.2 & 4.3 & 4.1 \\
\hline \multirow{4}{*}{$\begin{array}{l}\text { Cooked meat } \\
\text { flavor }\end{array}$} & $\mathrm{C}$ & 3.2 & 3.3 & 3.5 & 3.5 \\
\hline & $\mathrm{T} 1$ & 3.3 & 3.4 & 3.5 & 3.4 \\
\hline & $\mathrm{T} 2$ & 3.4 & 3.2 & 3.6 & 3.3 \\
\hline & T3 & 3.4 & 3.3 & 3.6 & 3.5 \\
\hline \multirow{4}{*}{$\begin{array}{c}\text { Cooked meat } \\
\text { tenderness }\end{array}$} & $\mathrm{C}$ & 3.6 & 3.8 & 4.0 & 4.1 \\
\hline & $\mathrm{T} 1$ & 3.5 & 3.8 & 3.9 & 4.2 \\
\hline & $\mathrm{T} 2$ & 3.5 & 3.6 & 3.8 & 4.1 \\
\hline & T3 & 3.4 & 3.7 & 3.8 & 4.0 \\
\hline \multirow{4}{*}{$\begin{array}{c}\text { Cooked meat } \\
\text { juiciness }\end{array}$} & $\mathrm{C}$ & 3.9 & 3.8 & 4.0 & 4.1 \\
\hline & $\mathrm{T} 1$ & 3.8 & 3.7 & 3.9 & 4.1 \\
\hline & $\mathrm{T} 2$ & 3.7 & 3.9 & 3.9 & 4.0 \\
\hline & T3 & 3.7 & 3.7 & 3.7 & 4.0 \\
\hline \multirow{4}{*}{$\begin{array}{l}\text { Cooked meat } \\
\text { acceptability }\end{array}$} & $\mathrm{C}$ & 4.2 & 4.3 & 4.5 & 4.4 \\
\hline & $\mathrm{T} 1$ & 4.1 & 4.2 & 4.5 & 4.6 \\
\hline & $\mathrm{T} 2$ & 4.2 & 4.4 & 4.4 & 4.5 \\
\hline & $\mathrm{T} 3$ & 4.2 & 4.3 & 4.6 & 4.6 \\
\hline
\end{tabular}

Color(5 : intensive, $1:$ poor), Flavor(5: good, 1:bed), Tenderness(5: soft, $1:$ tough), Juiciness(5: Juicy, $1:$ dry), Acceptability(5 : good, 1:bed).

${ }^{1)} \mathrm{C}$ : commercial diet, $\mathrm{T} 1$ : containing $0.2 \%$ glycine betaine, $\mathrm{T} 2$ : containing $0.4 \%$ glycine betaine, $\mathrm{T} 3$ : containing $0.6 \%$ glycine betaine.

$\mathrm{A}, \mathrm{B}, \mathrm{C}, \mathrm{D}$ Means in the same column with different letters are $\operatorname{different}(\mathrm{P}<0.05)$.

${ }_{a, b, c, d}$ Means in the same row with different letters are different $(\mathrm{P}<0.05)$.

타인 급여가 돈육 등심의 관능적 품질에 미치 는 영향은 없는 것으로 사료된다.

$$
\text { IV 요 약 }
$$

80 두의 3 원교잡종 돼지를 이용하여, 40 일간 글라이신 베타인이 함유된 시험사료를 급여한 후 도축하여 글라이신 베타인 급여가 돈육 등 심의 품질에 미치는 효과를 측정하였다. 돈육 등심내 글라이신 베타인의 축적율은 글라이신 베타인의 급여량이 높을수록 높게 나타났다 $(\mathrm{P}<$
0.05). $0.4 \%$ 글라이신 베타인 급여구는 저장기 간의 증가에 따라 등심육의 $\mathrm{pH}$ 가 유의적으로 $(\mathrm{P}<0.05)$ 증가하였으며, 저장 13 일에는 글라이 신 베타인 급여구가 대조구에 비교해 유의적으 로 $(\mathrm{P}<0.05)$ 높은 $\mathrm{pH}$ 를 나타내었다. 글라이신 베타인 급여 수준에 의한 명도값 $\left(\mathrm{L}^{*}\right)$ 은 유의적 인 차이를 나타내지 않았으며, 적색도(a) 또한 글라이신 베타인의 급여에 의한 주목할만한 경 향을 나타내지 않았다. 황색도 $\mathrm{b}$ *는 저장 9 일 에 $0.4 \%$ 와 $0.6 \%$ 글라이신 베타인 급여구가 대 조구와 $0.2 \%$ 글라이신 베타인 급여구에 비교해 
유의적으로 $(\mathrm{P}<0.05)$ 낮게 나타났다. 또한 저장 13 일에는 $0.6 \%$ 급여구가 가장 낮은 $(\mathrm{P}<0.05)$ 황 색도 값을 나타내었다. 글라이신 베타인 급여 에 의한 전단력 차이에서는 글라이신 베타인 급여구가 대조구에 비교해 유의적으로 $(\mathrm{P}<0.05)$ 높은 전단가를 나타내었다. 또한 저장 9 일까지 는 $0.4 \%$ 글라이신 베타인 급여구가 가장 높은 $(\mathrm{P}<0.05)$ 전단력을 나타내었으며, 저장 13 일에 는 $0.2 \%$ 글라이신 베타인 급여구가 유의적으로 $(\mathrm{P}<0.05)$ 가장 높은 전단력을 나타내었다. 근 절의 길이의 변화를 보면 $0.6 \%$ 글라이신 베타 인 급여구가 전 저장기간동안 가장 짧은 $(\mathrm{P}<$ $0.05)$ 근절길이를 나타내었으며, 대조구의 근절 길이는 전 저장기간동안 가장 길게 나타났다. 지방산패도의 변화는 저장기간이 경과할수록 모든 처리구의 지방산패도는 유의적으로 $(\mathrm{P}<$ 0.05 ) 증가하였으나, 처리구간의 지방산패도는 전 저장기간동안 유의적인 차이를 나타내지 않 았다. 글라이신 베타인의 급여에 의해 불포화 지방산의 함량은 감소하고 포화지방산의 함량 은 증가하는 결과를 나타내었다. 특히 linoleic acid와 myristic acid는 글라이신 베타인의 급여 수준이 높을수록 감소하는 $(\mathrm{P}<0.05)$ 경향을 나 타내었다. 신선육의 관능검사에서 육색은 저장 1 일차에 글라이신 베타인 급여구가 대조구에 비교해 유의적으로 $(\mathrm{P}<0.05)$ 높게 나타났으나 저장기간이 경과한 이후에는 처리구간의 육색 은 차이가 나타나지 않았다. 그러나 신선육 육 향과 전체적인 기호도 및 가열육 관능검사는 처리구간의 주목할만한 차이를 나타내지 않았 다.

\section{$\mathrm{V}$ 인 용 문 헌}

1. Brown, W. D. and Mebine, L. B. 1969. Autoxidation of oxymyoglobins. J. Bio. Chem. 244:6696-6701.

2. Campbell, R. G., Cadogan, D. J., Morley, W. C., Uusitalo, R. and Virtanen, E. 1995. Interrelationships between dietary methionine and betaine on the growth performance of pigs from 65 to $100 \mathrm{~kg}$. J. Anim. Sci. 73(Suppl. 1):82(Abstr.).

3. Campbell, R. G., Morley, W. C. and Zabaras- Krick. B. 1997. The effects of betaine on protein and energy metabolism of growing pigs. In: P. D. Cranwell(ed.) Manipulating Pig Production VI. p 243.
Australasian Pig Science Assoc., Werribee, Australia.

4. Cardogan, D. J., Campbell, R. G., Harrison, D. and Edwards, A. C. 1993. The effects of betaine on the growth performance and carcass characteristics of female pigs. In: E. S. Batterham(ed.) Manipulating Pig Production IV. pp219. Australasian Pig Science Association, Attwood, Victoria, Australia.

5. Casarin, A., Forat, M. and Zabaras-Krick, B. J. 1997. Interrelation-ships between-betaine(Betafin-BCR) and level of feed intake on the performance parameters and arcass characteristics of growing-finishing pigs. J. Anim. Sci. 75(Suppl. 1):75(Abstr.)

6. Cromwell, G. L., Lindemann, M. D., Randolph, J. R., Monegue, H. J., Laurent, K. M. and Parker, G. R. 1999. Efficacy of betaine as a carcass modifier in finishing pigs fed normal and reduced energy diets. J. Anim. Sci. (Suppl. 1):179(Abst.).

7. de Zwart, F. J., Slow, S., Payne, R. J., Lever, M., George, P. M. and Gerrard, J. A. 2003. Glycine betaine and glycine betaine analogues in common foods. Food Chemistry. 83:197-204.

8. Dellow, W. J., Chambers, S. T., Lever, M., Lunt, H and Robson, R. A. 1999. Elevate glycine betaine excretion in diabetes mellitus patients is associated with proximal tube dysfunction and hyperglycemia. Diabetes Research and Clinical Practice. 43:91-99.

9. Etherington, D. J., Taylor, M. A. J., Wakefield, D. K., Cousins, A. and Dransfield, E. 1990. Proteinase (cathepsin, B, D. L. and calpains) levels and conditioning rates in normal, electrically stimulalted and high-ultimate-pH chicken muscle. Meat Sci. 28:99-109.

10. Fernandez, C., Gallego, L. and Lopez-Bote, C. J. 1998. Effect of betaine on fat content in growing lambs. Animal Feed Science and Technology. 73: 329-338.

11. Geesink, G. H. 1995. Postmortem muscle proteolysis and beef tenderness with special reference to the action of the calpain/calpastatin system. Ph. D. Disertation. Utecht, The Netherland.

12. Greaser, M. L. 1986. In: Muscle as food. Conversion of muscle to meat. Academic Press, New York.

13. Haydon, K. D., Campbell, R. G. and Prince, T. J. 1995. Effect of dietary betaine additions and amino:calorie ratio on performance and carcass traits of finishing pigs. J. Anim. Sci. 73(Suppl. 1):83(Abstr.).

14. Hedrick, H. B., Aberle, E. D., Forrest, J. C., Judge, M. D. and Merkel, R. A. 1994. Principles of meat science. 3rd ed. Kendall/Hunt Publishing Co., Dubuque, IA.

15. Herring, H. K., Cassens, R. G. and Briskey, E. J. 1965. Further studies onbovine muscle tenderness as influenced by carcass position, sarcomere length, and fiber diameter. J. Food Sci. 30:1049-1054.

16. Honikel, K. O., Kim, C. J., Hamm, R. and Roncales. 
1986. Sarcomere shortening of prerigor muscles and its influence on drip loss. Meat Sci. 16:267-282.

17. Kauffman, R. G. and Marsh, B. B. 1987. In the science of meat and meat products. 3rd. eds. J. F. Price and B. S. Scheigert. Food and Nutrition Press, Inc., Westport. CT. USA. p. 349.

18. Lawrence, B. V., Schinckel, A. P., Adeola, O. and Cera, K. 2002. Impact of betaine on pig finishing performance and carcass composition. J. Anim. Sci. 80:475-482.

19. Lawrence, B. V., Schinckel, A. P., Adeola, O. and Cera, K. 1995. Performance of pigs fed betaine from 60 to $110 \mathrm{~kg}$ body weight. J. Anim. Sci. 73(Suppl. 1):195(Abstr.).

20. Lawrie, R. A. 1991. The eating quality of meat color. In Meat Science, 5 Edition, pp. 184-190. Pergamon Press Inc. New York.

21. Ledward, D. A. and Macfarlane, J. J. 1971. Some observations on myoglobin and lipid oxidatin in frozen beef. J. Food Sci. 36:987-990.

22. Matthews. J. O., Southern, L. L., Bidner, T. D. and Persica, M. A. 2001a. Effects of betaine, pen space, and slaughter handling method on growth performance, carcass traits, and pork quality of finishing barrows. J. Anim. Sci. 79:967-974.

23. Matthews. J. O., Southern, L. L. and Pontif, J. E. 1995. Effect of betaine(Betafin-BCR) on growth and carcass characteristics of finishing pigs. J. Anim. Sci. 73(Suppl. 1):195(Abstr).

24. Matthews. J. O., Southern, L. L., Pontif, J. E., Higbie, A. D. and Binder, T. D. 1998. Interactive effects of betaine, crude protein, and net energy in finishing pigs. J. Anim. Sci. 76:2444-2455.

25. Matthews, J. O., Soughern, L. L., Higbie, A. D., Persica, M. A. and Bidner, T. D. 2001b. Effects of betaine on growth, carcass characteristics, pork quality, and plasma metabolites of finishing pigs. J. Anim. Sci. 79:722-728.

26. O'Halloran, G. R., Troy, D. J., Buckley, D. J. and Reville, W. J. 1997. The relationship between early postmortem $\mathrm{pH}$ and the tenderisation of beef muscles. Meat Sci. 45:239-251.

27. Øveland, M., RØrvik, K. A. and Skrede, A. 1999. Effect of trimethylamine oxide and betaine in swine diets on growth performance, carcass characteristics, nutrient digestibility and sensory quality of pork. J. Anim. Sci. 77:2143-2153.

28. Page, J. K., Wulf, D. M. and Schwotzer, T. R. 2001. A survey of beef muscle color and pH. J. Anim. Sci. 79:678-687.

29. Saunderson, C. L. and Mackinlay, J. 1990. Changes in body weight, composition and hepatic enzyme activities in response to dietary methionine, betaine and choline levels in growing chicks. Br. J.
Nutr. 63:339-349.

30. Silva, J. A., Patarata, L. and Martins, C. 1999. Influence of ultimate $\mathrm{pH}$ on bovine meat tenderness during ageing. Meat Sci. 52:453-459.

31. Sizeland, P. C. B., Chambers, S. T., Lever, M., Bason, L. M. and Robson, R. A. 1993. Organic osmolytes in human and other mammalian kidneys. Kidney International. 43:448-453.

32. Smith, J. W., Nelssen, J. L., Goodband, R. D., Tokach, M. D., Richert, B. T., Owen, K. Q., Bergstrom, J. R. and Blum, S. A. 1995. The effects of supplementing growing-finishing swine diets with betaine and choline on growth and carcass characteristics. J. Anim. Sci. 73(Suppl. 1):83(Abstr.).

33. Smulders, F. J. M., Marsh, B. B., Swartz, D. R., Russell, R. L. and Hoenecke, M. E. 1990. Beef tenderness and sarcomere length. Meat Sci. 26:89-99.

34. Takahashi, G., Wang, S. M., Lochner, J. V. and Marsh, B. B. 1987. Effect of $2-\mathrm{Hz}$ and $60-\mathrm{Hz}$ electrical stimulation on the microstructure of beef. Meat Sci. 19:65-76.

35. Tornberg, E. 1996. Biophysical aspects of meat tenderness. Meat Sci. 43:175-191.

36. Virtanen, E. and Campbell, R. 1994. Reduzierung der Ruckenspeckdicke durch Einsatz von betaine bei Mastchweinen. Handbuch der tierischen Veredlung. Verlag H. Kamlage, Onsnabruek, Deutschland, 19:145-150.

37. Voyle, C. A. 1971. Sarcomere length and meat quality. 17th European meeting of meat Research Works. 95.

38. Warren, L. K., Lawrence, L. M. and Thompson, K. N. 1999. The influence of betaine on untrained and trained horses exercising to fatigue. J. Anim. Sci. 77:677-684.

39. Watanabe. A., Daly, C. C. and Devine, C. E. 1996. The effects of the ultimate $\mathrm{pH}$ of meat on tenderness changes during ageing. Meat Sci. 42:67-78.

40. Wheeler, T. L., Shackelford, S. D. and Koohmaraie, M. 2000. Variation in proteolysis, sarcomere length, collagen content, and tenderness among major pork muscles. J. Anim. Sci. 78:958-965.

41. Wood, J. D., Richardson, R. I., Nute, G. R., Fisher, A. V., Campo, M. M., Kasapidou, E., Sheard, P. R. and Enser, M. 2003. Effect of fatty acid on meat quality: a review. 66:21-32.

42. Zhu, L. G. and Brewer, M. S. 1998. Discoloration of fresh pork as related to muscle and display conditions. J. Food Sci. 63:763-767.

(접수일자 : 2004. 6. 30./ 채택일자 : 2004. 10. 18.) 
Park et al. ; Effect of Dietary Glycine Betaine on Meat Quality

Glycine betaine (mg) 